Syntax Literate: Jurnal Ilmiah Indonesia p-ISSN: 2541-0849 e-ISSN: 2548-1398

Vol. 6, No. 7, Juli 2021

\title{
PENGARUH KEPEMIMPINAN TRANSAKSIONAL TERHADAP MOTIVASI KERJA DI PT. MAHAMERU MEKAR DJAYA
}

\section{Jesslyn Kartawidjaja}

Fakultas Ekonomi, Magister Manajemen Universitas Katolik Parahyangan (UNPAR) Bandung, Jawa Barat, Indonesia

Email: jesslyn.kartawidjaja@gmail.com

\begin{abstract}
Abstrak
Motivasi kerja karyawan merupakan sesuatu yang dipercaya dapat mendorong karyawan, baik individu maupun kelompok untuk dapat memiliki semangat dalam bekerja. Dalam upaya meningkatkan motivasi kerja, kontribusi dari pemimpin sangat diperlukan, dan salah satu gaya kepemimpinan yang dipercaya dapat meningkatkan motivasi kerja karyawan yaitu kepemimpinan transaksional. Kepemimpinan transaksional adalah gaya kepemimpinan di mana berfokus kepada transaksi atau pertukaran yang terjadi di antara pemimpin dan bawahannya. Metode penelitian yang digunakan dalam penelitian ini ialah metode penelitian deskriptif. Penelitian ini menggunakan teknik analisis statistik deskriptif dan analisis regresi linear sederhana. Responden penelitian didapat dengan menggunakan sensus survei yakni seluruh populasi menjadi responden dalam penelitian ini yaitu sebanyak 40 orang dari karyawan PT. Mahameru Mekar Djaya. Hasil akhir dari penelitian ini menunjukkan bahwa kepemimpinan transaksional yang diterapkan oleh Manajer PT. Mahameru Mekar Djaya termasuk dalam kategori yang sangat kuat, sehingga karyawan memiliki motivasi kerja yang tinggi. Dari analisis regresi sederhana didapat hasil bahwa kepemimpinan transaksional memiliki pengaruh positif dan signifikan terhadap motivasi kerja yakni sebesar 32,7\%.
\end{abstract}

Kata Kunci: kepemimpinan; kepemimpinan transaksional; motivasi kerja

\section{Abstract}

Employee work motivation is something that is believed to encourage employees, both individuals and groups to be passionate about work. In an effort to increase work motivation, the contribution of the leader is needed, and one of the leadership styles that are believed to increase employee motivation is transactional leadership. Transactional leadership is a leadership style in which the focus is on transactions or exchanges that occur between leaders and their subordinates. The research method used in this research is descriptive research method. This study uses descriptive statistical analysis techniques and simple linear regression analysis. Research respondents were obtained by using a census survey, namely the entire population became respondents in this study, that is 40 people from employees of PT. Mahameru Mekar Djaya. The final result of this research shows that the transactional leadership applied by the Manager of PT. Mahameru Mekar Djaya is included in the very strong category, so employees have high work motivation.

$\begin{array}{lllll}\text { How to cite: } & \text { Kartawidjaja, Jesslyn (2021) Pengaruh Kepemimpinan Transaksional Terhadap Motivasi Kerja di PT. } \\ & \text { Mahameru Mekar Djaya. Syntax Literate: Jurnal Ilmiah Indonesia. } & \text { 6(7). } \\ & \text { http://dx.doi.org/10.36418/syntax-literate.v6i7.3504 } & & \\ \text { E-ISSN: } & 2548-1398 & & & \\ \text { Published by: } & \text { Ridwan Institute }\end{array}$


From simple regression analysis, it is found that transactional leadership has a positive and significant influence on work motivation, which is $32.7 \%$.

Keywords: leadership; transactional leadership; work motivation

\section{Pendahuluan}

Motivasi kerja adalah salah satu unsur yang esensial di dalam sebuah organisasi karena dapat memberikan energi yang berguna dalam menggerakkan segala usaha dan potensi yang ada, mendukung tingkah laku karyawan agar memiliki keinginan untuk bekerja dengan giat, meningkatkan gairah kebersamaan, serta antusias untuk mencapai hasil yang tinggi dan optimal. David McClelland menyampaikan bahwa setiap orang memiliki tiga kebutuhan dasar yang dapat memengaruhi motivasinya, yaitu kebutuhan akan berprestasi, kebutuhan akan berkuasa, dan kebutuhan akan berafiliasi (Mangkunegara, 2016). Kebutuhan akan berprestasi yaitu refleksi dari dorongan akan usaha dan hasil yang lebih baik, berusaha keras untuk berhasil, serta mencapai batasan/ standar yang tinggi. Kebutuhan akan kekuasaan yaitu dorongan/ upaya untuk mencapai otoritas/ kekuasaan yang dapat memengaruhi orang lain. Ketiga yaitu kebutuhan akan afiliasi, yakni keinginan untuk memiliki suatu hubungan antar-personal yang ramah, harmonis, dan akrab (Mangkunegara, 2016).

Motivasi kerja yang tinggi dapat tercapai apabila pemimpin dapat mendorong, mengarahkan, menggerakkan, dan memengaruhi karyawannya untuk memperoleh suatu sasaran/ tujuan tertentu. Untuk itu, suatu gaya kepemimpinan memiliki kontribusi/ peran yang penting untuk memengaruhi dan meningkatkan motivasi kerja demi mencapai tujuan organisasi yang telah ditetapkan (Gopal \& Chowdhury, 2014). Kepemimpinan merupakan cara atau norma yang digunakan oleh seseorang untuk memengaruhi orang lain yang dilihatnya (Pujiastuti, 2017). Untuk dapat memengaruhi, mendorong, mengajak, menuntun, dan mengarahkan bawahan atau kelompok untuk siap menerima pengaruh tersebut dan selanjutnya berbuat sesuatu yang dapat membantu tercapainya suatu tujuan tertentu yang telah ditetapkan, maka pemimpin harus memiliki kemampuan dan kesiapan yang mumpuni (Kamaludin, 2016).

Kepemimpinan transaksional adalah gaya kepemimpinan yang berfokus kepada transaksi atau pertukaran yang terjadi di antara pemimpin dan bawahannya. (Natalius, 2011) menyebutkan bahwa kepemimpinan transaksional merupakan gaya kepemimpinan yang paling banyak ditemui dalam kehidupan sehari-hari. Kepemimpinan transaksional dalam (Natalius, 2011) dibagi menjadi tiga dimensi yaitu, imbalan kontingen (contingent reward), manajemen eksepsi aktif (management by exception active), dan manajemen eksepsi pasif (management by exception passive).

Imbalan kontingen (contingent reward) merupakan bentuk kesepakatan atau pertukaran antara pemimpin dan bawahan, yang mana bawahan akan menerima imbalan tertentu atas tugas atau pekerjaan yang telah diupayakannya (Dartey-Baah Kwasi, 2015). Manajemen eksepsi aktif (management by exception active) memiliki arti bahwa pemimpin mengawasi dan mencari kesalahan atau penyimpangan yang tidak sesuai dengan aturan atau standar perusahaan. Manajemen eksepsi pasif (management by 
exception passive) merupakan kebalikan dari manajemen eksepsi aktif, yang mana pemimpin hanya akan melibatkan diri/ melakukan intervensi, memberi koreksi dan kritik hanya apabila hasil kerja tidak tercapai (pasif).

PT. Mahameru Mekar Djaya merupakan sebuah perusahaan yang didirikan sejak tahun 2014 dan bergerak di bidang distribusi barang kebutuhan sehari-hari, seperti makanan, minuman, sabun, shampoo, deterjen, pewangi pakaian, dan lain sebagainya. Dari hasil penelitian pendahuluan yang telah dilakukan sebelumnya, diyakini bahwa terdapat motivasi kerja karyawan yang rendah, pada karyawan PT. Mahameru Mekar Djaya. Untuk itu penelitian ini bertujuan untuk mengetahui apakah Manajer PT. Mahameru Mekar Djaya telah melakukan gaya kepemimpinan transaksional dan seberapa kuat gaya kepemimpinan transaksional yang telah dilakukannya tersebut, bagaimana tingkat motivasi kerja karyawan PT. Mahameru Mekar Djaya, serta bagaimana pengaruh dari kepemimpinan transaksional terhadap motivasi kerja karyawan PT. Mahameru Mekar Djaya tersebut. Penelitian ini diharapkan dapat memberikan manfaat bagi perkembangan perusahaan ke arah yang lebih baik, khususnya dalam hal menerapkan gaya kepemimpinan yang dapat meningkatkan motivasi kerja karyawan.

\section{Metode Penelitian}

Penelitian ini menggunakan metode deskriptif yang bertujuan untuk memberikan gambaran atau pemaparan mengenai permasalahan yang diteliti berdasarkan data. Data tersebut kemudian disajikan, dianalisis, dan diinterpretasikan (Sekaran \& Bougie, 2016). Berdasarkan tujuannya, penelitian ini termasuk ke dalam penelitian terapan (applied research), di mana hasil dari penelitian ini dimaksudkan untuk mengungkap fenomena yang terjadi dan membantu perusahaan untuk menyelesaikan permasalahan yang sedang dihadapi (Sekaran \& Bougie, 2016). Teknik analisis data yang digunakan adalah analisis statistik deskriptif dan analisis regresi linear sederhana. Dalam hal pengumpulan data dengan menggunakan kuesioner, penelitian ini menggunakan kuesioner yang diadopsi dan dikembangkan dari Multifactor Leadership Questionnaire (MLQ) (Kartawidjaja, 2020). Untuk mengukur motivasi kerja, penelitian ini menggunakan kuesioner dari The Personal Value Questionnaire (Gunawan, 2018).

Penelitian ini dilakukan di PT. Mahameru Mekar Djaya yang beralamat di Jalan Soekarno Hatta Nomor 736, Kelurahan Cimincrang, Kecamatan Gedebage, Kotamadya Bandung, Jawa Barat. Dengan menggunakan sensus survei, di mana seluruh anggota populasi akan dijadikan responden penelitian yakni dengan jumlah 40 orang karyawan. Seluruh responden merupakan tenaga kerja yang tergolong ke dalam usia produktif, yang mana tidak terdapat karyawan di bawah umur maupun yang memiliki usia di atas 55 tahun. Responden terbanyak adalah karyawan yang usianya di antara 36-45 tahun dengan jumlah responden sebanyak 21 orang dan memiliki persentase sebesar 52,5\%.

Adapun langkah-langkah yang dilakukan dalam pengolahan data tersebut adalah sebagai berikut:

a. Uji Validitas dan Uji Reliabilitas 
1. Teknik pengujian untuk mengetahui validitas masing-masing indikator dari variabel kepemimpinan transaksional dan motivasi kerja adalah dengan memperhatikan nilai Corrected Item-Total Correlation. Setiap indikator dinyatakan valid jika memiliki nilai Corrected Item-Total Correlation atau korelasi lebih besar dari 0,3 (Sulistyastuti, 2017).

2. Teknik pengujian untuk mengetahui reliabilitas masing-masing indikator dari variabel kepemimpinan transaksional dan motivasi kerja adalah dengan melihat nilai Cronbach's Alpha. Instrumen dikatakan reliabel apabila memiliki nilai Cronbach's Alpha yaitu lebih besar dari 0,6 (Gunawan, 2018).

b. Analisis Statistik Deskriptif

Analisis statistik deskriptif yaitu analisis data dengan menggambarkan atau mendeskripsikan data pada setiap variabel penelitian yang berguna untuk melihat gambaran secara umum penilaian dari responden untuk masing-masing penelitian (Gunawan, 2018). Penyajian data dalam penelitian ini menggunakan rata-rata data dari jawaban setiap responden untuk diolah dan dianalisis. Kategori variabel kepemimpinan transaksional dan motivasi kerja adalah sebagai berikut:

\section{Tabel 1}

Kategori Variabel Kepemimpinan Transaksional Dan Motivasi Kerja

\begin{tabular}{cccc}
\hline Kategori & $\begin{array}{c}\text { Nilai Rata- } \\
\text { rata }\end{array}$ & $\begin{array}{c}\text { Kepemimpinan } \\
\text { Transaksional }\end{array}$ & Motivasi Kerja \\
\hline 1. & $1,0-2,0$ & Lemah & Rendah \\
\hline 2. & $2,01-3,0$ & Cukup Kuat & Cukup Tinggi \\
\hline 3. & $3,01-4,0$ & Kuat & Tinggi \\
\hline 4. & $4,01-5,0$ & Sangat Kuat & Sangat Tinggi
\end{tabular}

c. Uji Normalitas

Uji normalitas data bermaksud untuk menguji apakah model regresi, variabel terikat dan variabel bebas keduanya memiliki distribusi normal atau tidak (Nurwisda \& Rosyadi, 2018). Data yang layak dan baik digunakan dalam penelitian yaitu data yang memiliki distribusi normal. Dalam penelitian ini penulis menggunakan cara dengan memperhatikan kurva normal P-plot. Menurut Singgih Santoso, terdapat beberapa cara untuk mendeteksi normalitas dengan melihat penyebaran data (titik) pada sumbu diagonal dari grafik yaitu (Nafidah, 2015):

- Jika data menyebar di sekitar garis diagonal dan mengikuti arah garis diagonal, maka regresi memenuhi asumsi normalitas.

- Jika data menyebar dari garis diagonal dan atau tidak mengikuti arah garis diagonal, maka model regresi tidak memenuhi asumsi normalitas.

d. Uji Linearitas

Uji linearitas digunakan untuk mengetahui apakah dua variabel yang diuji memiliki hubungan yang linear secara signifikan ataukah sebaliknya. Dasar pengambilan keputusan uji linearitas dalam penelitian ini yaitu dengan melihat nilai signifikansinya (Sig.) (Raharjo, 2014). 
- Jika nilai Deviation from Linearity Sig. > 0,05, maka terdapat hubungan yang linear secara signifikan antara variabel independen dengan variabel dependen.

- Jika nilai Deviation from Linearity Sig. < 0,05, maka tidak terdapat hubungan yang linear secara signifikan antara variabel independen dengan variabel dependen.

e. Uji Heteroskedastisitas

Uji heteroskedastisitas digunakan untuk menguji apakah terjadi perbedaan variansi (variance) dari nilai residual pada suatu periode pengamatan ke periode pengamatan yang lainnya (Uviyanti \& Pramuka, 2020). Untuk menguji heteroskedastisitas, penulis menggunakan cara dengan melihat pola gambar Scatterplots. Adapun pedoman yang digunakan untuk melihat pola gambar Scatterplots adalah sebagai berikut.

Tidak terjadi gejala atau masalah heteroskedastisitas apabila (Raharjo, 2017):

- Titik-titik data penyebar di atas dan di bawah atau di sekitar angka 0.

- Titik-titik tidak mengumpul hanya di atas atau di bawah saja.

- Penyebaran titik-titik data tidak boleh membentuk pola bergelombang melebar kemudian menyempit dan melebar kembali.

- Penyebaran titik-titik data tidak berpola.

f. Analisis Regresi Linear

Analisis regresi linear bertujuan untuk mengetahui arah hubungan antara variabel independen dengan variabel dependen, apakah positif atau negatif serta untuk memprediksi nilai dari variabel dependen apabila nilai variabel independen mengalami kenaikan atau penurunan. Persamaan umum regresi linear sederhana (Sugiyono, 2018) adalah:

$$
\boldsymbol{Y}=\boldsymbol{a}+\boldsymbol{b x}
$$

Keterangan:

$\mathrm{Y}^{\prime}=$ Subjek/ nilai dalam variabel dependen yang diprediksikan.

a $=$ Harga $\mathrm{Y}$, bila $\mathrm{X}=0$ (harga konstan)

$\mathrm{b}=$ Angka arah atau koefisien regresi, yang menunjukkan angka peningkatan ataupun penurunan variabel dependen yang didasarkan pada variabel independen. Apabila b (+) maka naik, dan bila b (-), maka terjadi penurunan.

$\mathrm{X}=$ Subjek pada variabel independen yang mempunyai nilai tertentu.

Analisis regresi linear sederhana ini dilakukan dengan bantuan program Statistical Package for the Social Sciences (SPSS).

\section{Hasil dan Pembahasan}

Semua indikator dari variabel kepemimpinan transaksional dan motivasi kerja dinyatakan valid dikarenakan semua indikator mempunyai nilai Corrected Item-Total Correlation lebih besar dari 0,3. Hasil pengukuran reliabilitas kepemimpinan transaksional dan motivasi kerja dinyatakan reliabel karena semua indikator memiliki nilai Cronbach's Alpha lebih besar dari 0,6. 
Berdasarkan analisis deskriptif variabel kepemimpinan transaksional, didapat hasil bahwa dimensi imbalan kontingen memiliki nilai rata-rata sebesar 4,04 dengan kategori sangat kuat. Artinya, praktek kepemimpinan yang didasarkan pada kesepakatan antara atasan dengan bawahan untuk mencapai tujuan yang telah disepakati dirasakan sangat kuat oleh para karyawan. Ketika karyawan memperlihatkan hasil kerja yang sesuai dengan standar yang telah ditentukan, maka karyawan akan memperoleh penghargaan, pengakuan ataupun imbalan yang sesuai. Dimensi manajemen eksepsiaktif memperoleh nilai rata-rata sebesar 4,11 yang memiliki kategori sangat kuat. Hal ini menunjukkan bahwa karyawan merasakan sangat kuat perilaku pemimpin yang secara aktif melakukan pengawasan terhadap kemungkinan terjadinya penyimpangan, kesalahan dan kegagalan dalam pelaksanaan tugas serta mengambil tindakan perbaikan yang diperlukan. Dimensi manajemen eksepsi-pasif memperoleh nilai rata-rata sebesar 4,22 dengan kategori sangat kuat. Dengan demikian dapat disimpulkan bahwa karyawan merasakan sangat kuat perilaku pemimpin yang cenderung bersifat menunggu (pasif). Pemimpin akan mengambil tindakan ketika terjadi penyimpangan, kesalahan, maupun kegagalan. Kepemimpinan transaksional memiliki nilai rata-rata total yakni sebesar 4,11 dengan kategori sangat kuat. Dengan demikian dapat disimpulkan bahwa Manajer PT. Mahameru Mekar Djaya telah menerapkan gaya kepemimpinan transaksional di dalam perusahaan dan karyawan merasakan sangat kuat kepemimpinan yang berfokus kepada transaksi atau pertukaran yang terjadi di antara pemimpin dan bawahannya.

Dari hasil analisis deskriptif pada variabel motivasi kerja, diperoleh hasil bahwa dimensi kebutuhan akan pencapaian mempunyai nilai rata-rata yaitu sebesar 3,93 dengan kategori tinggi. Hal ini menunjukkan bahwa adanya dorongan yang tinggi dari karyawan untuk berusaha maksimal, memiliki keinginan untuk mencapai prestasi yang tinggi, serta mencapai standar-standar yang telah ditetapkan oleh perusahaan. Dimensi kebutuhan akan kekuasaan memperoleh nilai rata-rata yaitu sebesar 3,30 dengan kategori tinggi. Berdasarkan nilai tersebut, maka dapat terlihat bahwa karyawan memiliki dorongan yang tinggi untuk dapat memengaruhi dan mengendalikan orang lain. Dimensi kebutuhan akan afiliasi memperoleh nilai rata-rata yaitu sebesar 3,76 dengan kategori tinggi. Dengan besarnya nilai tersebut, maka menunjukkan adanya dorongan yang tinggi dari karyawan untuk menjalin suatu hubungan antar personal yang akrab dan erat. Untuk nilai rata-rata total dari variabel motivasi kerja, diperoleh nilai sebesar 3,31 dengan kategori tinggi. Pada akhirnya dapat disimpulkan bahwa motivasi kerja karyawan di PT. Mahameru Mekar Djaya termasuk ke dalam kategori yang tinggi.

Berdasarkan hasil uji P-plot, dapat dilihat titik-titik yang mengikuti dan mendekati garis diagonalnya. Berdasarkan kurva tersebut, maka dapat disimpulkan bahwa data penelitian ini memiliki penyebaran dan berdistribusi normal. Oleh karena itu, penelitian ini dapat dilanjutkan.

Dari nilai signifikansi (Sig.) yang diperoleh pada hasil uji linearitas, nilai Deviation from Linearity Sig. yang didapat adalah sebesar 0,631 yang mana nilai tersebut lebih besar dari 0,05 . Oleh karena itu, dapat disimpulkan bahwa terdapat 
hubungan linear yang signifikan antara variabel independen (kepemimpinan transaksional) dengan variabel dependen (motivasi kerja).

Berdasarkan hasil uji Scatterplot untuk menguji heteroskedastisitas, diperoleh penyebaran titik-titik data yang menyebar di atas dan di bawah atau di sekitar angka 0 . Titik-titik data tidak mengumpul hanya di satu titik, baik di atas ataupun di bawah saja. Penyebaran titik juga tidak membentuk suatu pola tertentu. Oleh karena itu dapat disimpulkan bahwa tidak terjadi masalah heteroskedastisitas dalam penelitian ini, sehingga model regresi yang baik dan ideal telah terpenuhi.

Hasil persamaan regresi linear sederhana kepemimpinan transaksional (X) terhadap motivasi kerja (Y) adalah sebagai berikut:

\section{$Y=32,958+1,090 X$}

a = angka konstan dari unstandardised coefficients, bernilai 32,958. Angka ini merupakan angka konstan yang menunjukkan bahwa apabila tidak terdapat kepemimpinan transaksional (X), maka nilai konsisten dari Motivasi Kerja (Y) adalah sebesar 32,958.

$\mathrm{b}=$ angka koefisien regresi, bernilai 1,090. Artinya, bahwa setiap penambahan $1 \%$ tingkat kepemimpinan transaksional (X), maka motivasi kerja (Y) akan meningkat sebesar 1,090 .

Dari hasil persamaan regresi yang telah diperoleh, nilai koefisien regresi yang diperoleh memiliki nilai yang positif (+). Dengan demikian dapat dinyatakan bahwa kepemimpinan transaksional (X) memiliki pengaruh positif terhadap motivasi kerja (Y). Untuk nilai signifikansi (Sig.), diperoleh angka sebesar 0,000. Nilai signifikansi ini memiliki nilai yang lebih kecil dibandingkan dengan nilai probabilitas 0,05. Berdasarkan hasil tersebut, maka dapat disimpulkan bahwa kepemimpinan transaksional (X) berpengaruh secara signifikan terhadap motivasi kerja karyawan (Y).

Berdasarkan hasil analisis regresi linear sederhana ini pula dapat diketahui nilai $R$ Square yang didapat yaitu sebesar 0,327. Artinya, terdapat pengaruh kepemimpinan transaksional (X) terhadap motivasi kerja (Y) yaitu sebesar sebesar 32,7\% sedangkan sisanya yaitu sebesar $67,3 \%$ dipengaruhi oleh variabel lainnya yang tidak diketahui dan tidak termasuk di dalam penelitian ini.

Dari keseluruhan hasil analisis regresi linear sederhana di atas, dapat disimpulkan bahwa kepemimpinan transaksional memiliki pengaruh positif dan signifikan terhadap motivasi kerja yakni sebesar $32,7 \%$ dan sisanya sebesar $67,3 \%$ dipengaruhi oleh variabel lainnya yang tidak diketahui dan tidak termasuk ke dalam penelitian ini. Hasil penelitian ini selaras dengan penelitian yang dilakukan oleh (Anindhita, 2018) bahwa terdapat pengaruh yang positif dan signifikan dari gaya kepemimpinan transaksional terhadap motivasi kerja pada para pekerja di PD. Hollywood, serta penelitian yang dilakukan (Awan, 2020) bahwa secara simultan terdapat pengaruh yang signifikan dan positif antara kepemimpinan transaksional dengan motivasi kerja, serta didapat hasil 
bahwa dimensi imbalan kontingen merupakan yang paling memiliki pengaruh positif/ dominan terhadap motivasi kerja karyawan pada kantor PT. Wijaya Sukses Sejahtera di Kabupaten Berau.

\section{Kesimpulan}

Manajer Operasional dari PT. Mahameru Mekar Djaya Bandung telah menerapkan gaya kepemimpinan transaksional, dan karyawan Bagian Operasional merasakan sangat kuat gaya kepemimpinan transaksional yang telah diterapkan oleh Manajer Operasional tersebut. Pada umumnya karyawan Bagian Operasional PT. Mahameru Mekar Djaya Bandung memiliki motivasi kerja yang tinggi.

Berdasarkan hasil analisis regresi linear sederhana yang telah dilakukan, dapat diketahui bahwa kepemimpinan transaksional berpengaruh secara positif dan signifikan terhadap motivasi kerja yaitu sebesar 32,7\% dan sisanya sebesar 67,3\% dipengaruhi oleh variabel lainnya yang tidak diketahui. Dengan nilai pengaruh yang cukup kecil tersebut, yaitu sebesar $32,7 \%$, maka perlu dilakukan penelitian lebih lanjut untuk mencari variabel-variabel lainnya yang memiliki pengaruh yang lebih besar terhadap motivasi kerja karyawan dibandingkan dengan kepemimpinan transaksional. 


\section{BIBLIOGRAFI}

Anindhita, Nadya Radityani dan Jerry Marcellinus Logahan. (2018). Transactional Leadership: Improving Satisfaction, Performance, And Motivation Of The Employees at PD. Hollywood. Buku 2: "Hukum, Politik, Manajemen, Ekonomi, Akuntansi, Konseling, Desain, dan Seni Rupa." Seminar Nasional Cendekiawan $\mathrm{Ke} 4$.

Awan, Taruk Todingallo Delvi. (2020). Pengaruh kepemimpinan transaksional terhadap motivasi kerja karyawan pada kantor PT. Wijaya Sukses Sejahtera di Kabupaten Berau. Jurnal Administrasi Bisnis Fisipol Unmul, 8(3), 216-223. Google Scholar

Dartey-Baah Kwasi. (2015). Resilient leadership: a transformational-transactional leadership mix. Journal of Global Responsibility, 6(1), 99-112. Google Scholar

Gopal, R., \& Chowdhury, Rima Ghose. (2014). Leadership styles and employee motivation: An empirical investigation in a leading oil company in India. International Journal of Research in Business Management, 2(5), 1-10. Google Scholar

Gunawan. (2018). Analisis Hubungan Kepemimpinan Transformasional Dengan Motivasi Kerja Pegawai di Lembaga Pendidikan Tinggi (Studi Kasus di Universitas Katolik Parahyangan). Tesis. Program Magister Manajemen Pascasarjana Universitas Katolik Parahyangan Bandung.

Kamaludin, Kamaludin. (2016). Pengaruh Peran Kepemimpinan Kepala Sekolah Dan Iklim Sekolah Terhadap Kinerja Guru. Syntax Literate; Jurnal Ilmiah Indonesia, 1(3), 17-29. Google Scholar

Kartawidjaja, Jesslyn. (2020). Analisis Pengaruh Kepemimpinan Transaksional Dan Kepemimpinan Transformasional Terhadap Motivasi Kerja Karyawan Bagian Operasional PT. Mahameru Mekar Djaya Bandung. Tesis. Fakultas Ekonomi Program Magister Manajemen Universitas Katolik Parahyangan Bandung.

Mangkunegara, A. A. Anwar Prabu. (2016). Manajemen sumber daya manusia perusahaan. Bandung: PT. Remaja Rosdakarya. Google Scholar

Nafidah, Nurul. (2015). Pengaruh kinerja pustakawan terhadap kepuasan pemustaka pada perpustakaan universitas indonesia. 1-119. Google Scholar

Natalius, Frans. (2011). Analisa Kepemimpinan Transaksional dan Transformasional untuk meningkatkan Kerjasama Tim dan Kinerja Waktu Proyek (Studi Kasus pada Perusahaan PT. X). Indonesia University. Google Scholar

Nurwisda, Delaga, \& Rosyadi, Noor. (2018). Pengaruh Kebutuhan Fisiologis, Keamanan, Sosial, Penghargaan Dan Aktualisasi Diri Terhadap Prestasi Kerja Pegawai Puskesmas Petarukan Kab. Pemalang. Syntax Literate; Jurnal Ilmiah Indonesia , 3(10), 30-46. Google Scholar 
Pujiastuti, Endang. (2017). Hubungan Antara Kompetensi Profesional Tenaga Medis, Budaya Kerja Dan Gaya Kepemimpinan Dengan Mutu Pelayanan Pasien Rawat Inap Di Rumah Sakit Waled Kab. Cirebon. Syntax Literate; Jurnal Ilmiah Indonesia, 2(4), 34-65. Google Scholar

Raharjo, Sahid. (2014). . (). . pada tanggal 13 Juli 2020, pukul 11.54. In Cara Melakukan Uji Linearitas dengan Program SPSS. Retrieved from https://www.spssindonesia.com/2014/02/uji-linearitas-dengan-program-spss.html

Raharjo, Sahid. (2017). . (). . pada tanggal 13 Juli 2020, pukul 10.12. In Panduan Uji Heteroskedastisitas dengan Gambar Scatterplots SPSS. Retrieved from https://www.spssindonesia.com/2017/03/uji-heteroskedastisitas-scatterplots.html

Sekaran, Uma, \& Bougie, Roger. (2016). Research methods for business: A skill building approach. John Wiley \& Sons. Google Scholar

Sugiyono. (2018). Metode Penelitian Kuantitatif (Setiyawami (ed.)). Bandung: Alfabeta.

Sulistyastuti, Erwan Agus Purwanto dan Dyah Ratih. (2017). Metode Penelitian Kuantitatif. Yogyakarta: Gava Media.

Uviyanti, Siti, \& Pramuka, Bambang Agus. (2020). Pengaruh Sistem Informasi Akuntansi Terhadap Kualitas Laporan Bantuan Operasional Sekolah (Bos). Syntax Literate; Jurnal Ilmiah Indonesia, 5(7), 471-480. Google Scholar

\section{Copyright holder:}

Jesslyn Kartawidjaja (2021)

First publication right:

Syntax Literate: Jurnal Ilmiah Indonesia

This article is licensed under:

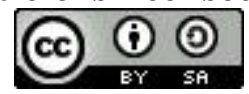

